\title{
Nativization and Formation of Collective Memory in Urban Design: a Semiotic Analysis of The Sultan Agung 2018 Movie Poster
}

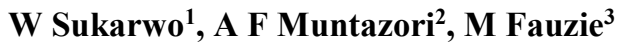 \\ ${ }^{123}$ Department of Design and Visual Communications, Faculty of Language and Art, \\ Universitas Indraprasta PGRI \\ faiz.muntazori@gmail.com
}

\begin{abstract}
As a form of urban culture, movies are closely related to the urban middle-class life. Movie posters as a cultural artifact as a part of urban design play a complex role in urban life, one of them is forming the collective memory within the society. The focus of this research is the Sultan Agung 2018 movie poster to observe the way cultural nativization works through the post-colonial framework. This nativization then synergized with the use of internet technology to form a collective memory of Sultan Agung in a way intended by the movie poster. The taxonomy of semiotics proposed by C.W. Morris was used to analyze the visual design to identify the signs of cultural nativization, The result shows that at the pragmatic level, there are indications of the work of cultural nativization as well as the de-Islamization of Indonesian history. Cultural nativization is closely related to the critical theory contained in the post-colonialism discourse. Cultural nativization contained in Sultan Agung 2018 movie poster is then seen as a legacy of colonial interests against this struggle for cultural identity of the Indonesian people.
\end{abstract}

Keywords: Sultan Agung, Movie Poster, Cultural Nativization, PostColonialism, Urban Design.

\section{INTRODUCTION}

In the era of information transparency and the increasing technological developments, visual artifact in the form of design has become a cultural artifact that is closely related to the development of urban society. Paradigms, mindsets, perspectives, and ideologies in society are always compressed in the contents presented in these artifacts visually. As an artifact of urban design, these visual products then fill public spaces which, in turns, play a role as a site of construction for collective memory spread within the community. 
One of the visual design products that are closely related to the urban lifestyle is movie poster. Movie posters as a cultural artifact as a part of urban design play a complex role in urban life, one of them is forming the collective memory within the society. Although sometimes not directly related to the content of the film, movie posters act as a visual representative of the content found within the movie which also carry a persuasive effect within the framework of industrial commodities. Movie posters are not a mere promotional media; they also play a very strategic cultural role in the form of constructing a collective memory of the community. A movie poster must even be able to evoke memories and attract someone's attention [1]. Movie posters are included in the articulation model that forming collective memory in the new era including internet and web sites [2].

Glorification of the pre-Islamic Indonesian history along with religious syncretism was formed, one of which was through the work of cultural nativization. In association with the problems faced by Indonesian Muslims, cultural nativization is starting to gain a momentum, weakening the legitimacy of the religious nationalist group (opposition for the Islam Nusantara discourse) towards Indonesian history and culture. However, long before all of these happened, Mohammad Natsir in [3] once reminded of the dangers of cultural nativization as one of the three biggest threats of Muslims in addition to apostasy and secularization. This thesis is in line with Syed Naquib Al-attas's statement about Islam in Indonesia that was built by orientalists. According to [4], Islam in Indonesia is not a mere wood veneer which when peeled off, reveals the internal face of Hinduism and Buddhism. Thus, the formed collective memory of the community is directly related to the work cultural nativization.

This study will analyze the movie poster of Sultan Agung produced in 2018 and directed by Hanung Bramantyo. This study revolves around the assumptions about the signs of cultural nativization on the Sultan Agung 2018 movie poster. This nativization then synergized with the use of internet technology to form a collective memory of Sultan Agung in a way intended by the movie poster. These assumptions are further examined and verified using semiotic analysis proposed by C.W.Morris to analyze the visual design of Sultan Agung 2018 movie poster to identify the signs of cultural nativization.

\section{METHOD}

This research is a qualitative type with urban design (movie posters) as an object. The data collection method is a document study as explained by [5]. Visual semiotics is used to perform stages of art criticism on the design of Sultan Agung 2018 movie poster. When referring to the elements of art criticism compiled by [6], visual semiotics in this study are practically used to form descriptions, formal analysis, and interpretations. This study uses the taxonomy of semiotics proposed by C.W. Morris in [7], who divides a visual sign in three levels, namely syntactics, semantics, and pragmatics just as seen in table 1. This Morris's taxonomy was once used to examine the visual character of editorial cartoons in Indonesia [8]. In the same way it will be applied to different objects, such as movie posters. 
Table 1. Taxonomy of Semiotics Proposed by Morris

\begin{tabular}{cccc}
\hline Level & Syntactic & Semantic & Pragmatic \\
\hline Attribute & $\begin{array}{c}\text { Study of the structure of } \\
\text { signs }\end{array}$ & $\begin{array}{c}\text { Study of the meaning of } \\
\text { signs }\end{array}$ & $\begin{array}{c}\text { Study of the effect of } \\
\text { signs }\end{array}$ \\
\hline \multirow{3}{*}{ Element } & $\begin{array}{c}\text { Signifier/Signified } \\
\text { Syntagma/System } \\
\text { Denotation/Connotation } \\
\text { Metaphor/Metonymy }\end{array}$ & $\begin{array}{c}\text { Denotation/Connotation } \\
\text { Ideology/Myths }\end{array}$ & $\begin{array}{c}\text { Postcolonialism } \\
\text { Identity Politics } \\
\text { Collective Memory }\end{array}$ \\
\hline
\end{tabular}

The analysis done at the pragmatic level on the Sultan Agung 2018 movie poster will be approached with postcolonial theory developed by many experts such as [9] and [10]. Postcolonial theory will be used as a critical theory to uncover all things caused by colonialism, especially the mentality of former colonized communities. The Sultan Agung 2018 movie poster is a product produced by former colonized communities with a mentality that can be deconstructed through the postcolonial theory approach.

\section{RESULT AND DISCUSSIONS}

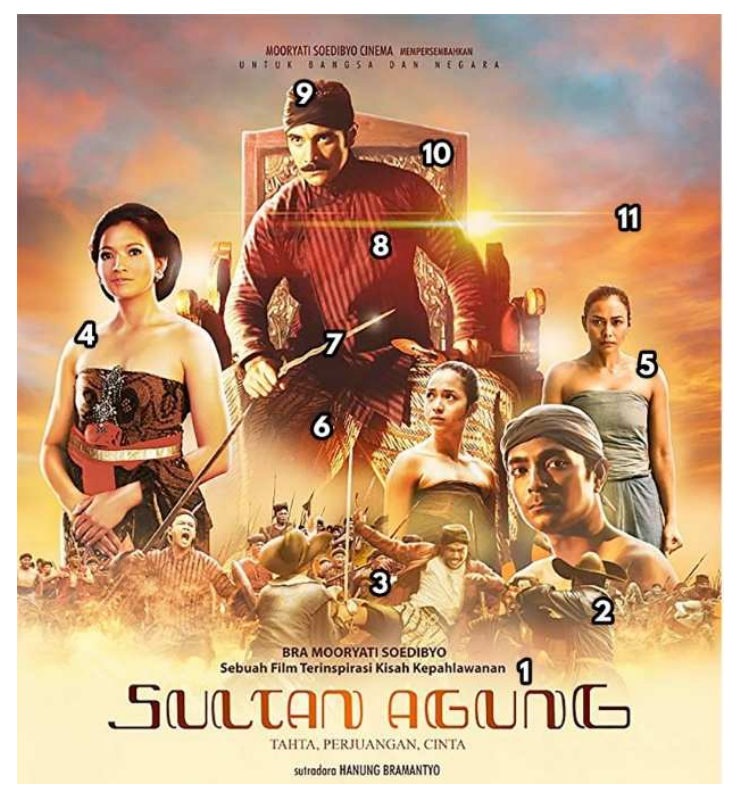

Figure 1. Official Sultan Agung 2018 Movie Poster and The Visual Elements Contained within

Figure 1 shows the official poster for Sultan Agung 2018 the movie. As shown in the figure 1 , the movie poster contained 11 visual elements that will be analyzed formally using the taxonomy of semiotics proposed by C.W. Morris. The 11 visual elements and their formal description is compiled and laid out in table 2 below. 
Table 2. Visual Elements of Sultan Agung 2018 Movie Poster and Their Formal Descriptions

\begin{tabular}{|c|c|c|}
\hline No. & Visual Element & Formal Description \\
\hline 1. & Movie title & $\begin{array}{l}\text { Written in Latin script akin to the character of Palawa letters } \\
\text { commonly used in pre-Islamic Javanese cultural texts. }\end{array}$ \\
\hline 2. & Dutch Colonial army & $\begin{array}{l}\text { A figure wearing typical Dutch Colonial army uniforms } \\
\text { during the colonialization of the Indonesian archipelago. }\end{array}$ \\
\hline 3. & Battle scene & $\begin{array}{l}\text { The scene picturing the invasion of Sultan Agung's forces to } \\
\text { Batavia. }\end{array}$ \\
\hline 4. & Woman 1 & Woman wearing Javanese traditional clothes. \\
\hline 5. & Woman 2 & Woman wearing Javanese traditional clothes. \\
\hline 6. & $\begin{array}{l}\text { Cloth bearing the } \\
\text { "Parang" motifs }\end{array}$ & Batik cloth adorned with traditional "Parang" motifs. \\
\hline 7. & Unsheathed Kris knife & Javanese traditional weapon. \\
\hline 8. & Lurik cloth & Javanese male traditional clothes. \\
\hline 9. & Blankon & Javanese male traditional headband called Blangkon. \\
\hline 10. & Throne & The throne of Javanese leaders. \\
\hline 11. & Dusk sky & Sky depicting dusk. \\
\hline
\end{tabular}

\subsection{Syntactics Analysis}

The dominant element found in the movie poster is pictorial element in the form of a photo. These photos are arranged using a digital collage technique to form a composition resembling a pyramid or a mountain with formal or symmetrical balance composition that divides the space in the movie poster into two almost equal area. The domination lies in the figure placed in the middle top of the pyramid that center the attention of the viewers. This figure depicts a man in traditional Javanese fashion system, which consists of blangkon from the type that can be taken off and used as a prayer mat (sutrah), a red-black stripe patterned Sorjan shirt, and an under cloth bearing the "Parang" motifs. Sorjan shirt is a Muslim attire created by Sunan Kalijaga. The "Parang" motif is a Batik motif exclusive for the use of Keraton (Javanese nobles) which is forbidden to be used by ordinary people. These two signs signify that the figure wearing this fashion system is a Javanese aristocrat and, at the same time, a Muslim. The throne he sat upon is a signifier, with the signified signifying high position. The central figure sits with both legs opened (njegeh). One hand is resting on the right thigh while holding an unsheathed Kris knife, a Javanese weapon, while the other hand holds a Kris scabbard and rests on the left thigh. Such gesture, coupled with sharp eyes, constituted as the signifier with the signified signifies anger.

Both sides of the composition featured female figures. One woman is standing closer to the front and wearing a Jarit cloth covering up to the chest area. This cloth is patterned which signifies that the wearer is of the nobility. The other woman stands further in the back, wearing a dull colored cloth without any motif, resembling the lowest quality cotton cloth. This signifies that the wearer is of ordinary people. The cloth covering the the woman's body up to her chest area is a typical Javanese traditional women's clothing style from the pre-Islamic Javanese era. Women often viewed as a metaphor for the homeland, a symbol of cultural mastery, and a symbol of generational continuity. The movie poster also features one other woman wearing commoner clothes and a young man with a headband. The latter two figures appear younger than the other figures. 


\subsection{Semantics Analysis}

The context of the posters was illustrating and promoting movie about the invasion of the Mataram armies against the Dutch Colonial fortress in Batavia. The Syntagma in this movie poster displays the main characters in the event. The central figure of this poster is Sultan Agung, who is represented by the male figure in the middle of the composition. Denotation of the syntagma is the movie poster of Sultan Agung that emphasizes Javanese ethnic visual identity. The connotation of the syntagma poster is the visualization of Sultan Agung, which emphasizes its Javanese aspects more than his Islamic ones. Furthermore, the connotation emphasized that the invasion battle launched by Sultan Agung is not associated with jihad fisabilillah (holy war in the way of Allah), but solely for political gains and power affairs. The ideology articulated in this poster is Javanese feudalism against Western colonialism.

In [11] record, Sultan Agung Anyakrakusuma (SA) attached the title Sunan to his name, which is usually only used by the wali (spreaders of Islam in Java). This signifies his great concern for Islam. On the other hand, the Dutch did not like the Sultanate of Mataram to be a strong Islamic empire. The contraction between them showed that the invasion of Sultan Agung to the VOC fortress in Batavia was fisabilillah war.

\subsection{Pragmatics Analysis: Collective Memory and Cultural Nativization}

Collective memory can be a complex problem in the future if it is related to a historical narrative which involving many interests [12]. The concept of collective memory refers to the thesis of [13] which links the process of remembering and forgetting at the same time. Collective memory refers to the ways that images, practices, political rhetoric, and objects, such as monuments and memorials, actively shape what is to be remembered [14]. According to [13], one's personal memory is directly related to the experiences that he collects in the public space. The memory is then transformed into a part of the collective memory when the forgetting process occurs. Furthermore, [15] said that the forgetting process could occur without our awareness through the process of meaning-making, performance, and conditioning. This forgetting process can occur through direct government or community intervention in an attempt to release unwanted memories and construct new desired memories.

At the time this article was written, when typing the word "Sultan Agung" into the Google search engine page, the images began to display the Sultan Agung 2018 movie by Hanung Bramantyo. The illustration of Sultan Agung, which is usually displayed in history books, began to be displayed side-by-side with the face of Ario Bayu, the actor who played the figure of Sultan Agung in the movie. The way search engines work is simple, the more netizens access an online link related to a keyword, the more it is placed on the starting page of the search engine. The more frequent a link is accessed by the netizens, the more it was pushed up the search engine's page. As a reference, on the first day the film was screened in the national cinema, the number of viewers reached 6,053 people (www.theatersatu.com, accessed August $24,2018)$. This figure is not a fantastic number for a movie in Indonesia, but it is enough to bring up conversations in cyberspace. Furthermore, Google as a company has a platform that allows cooperation to promote a product such as movies. Through a transaction, movie posters can land in priority space on the search page without needing a lot of access from the netizens.

Meanwhile, the movie poster clearly plays a central role in the discourse of de-Islamization in the Indonesian archipelago. This is shown by the pragmatics analysis that uncover the work 
of cultural nativization. In "Kamus Istilah Ilmu-Ilmu Sosial" compiled by [16], nativism is interpreted as any conscious and organized effort of a nation to revive or perpetuate selected aspects of their culture. Nativization is a term now universally used in linguistics [17], therefore visual sign like movie posters can be treated as language too. This cultural nativization has existed since the colonial period as part of a colonial strategy to weaken resistance from indigenous people in Indonesia, especially Muslims. Thomas Stamford Rafles, quoted by [18] says that every indigenous figure who has just returned from the Hajj in Mecca will be considered as 'sacred'. They were considered as very influential in driving the resistance of the indigenous people to oppose colonialism. This awareness then affected the manipulation of the writing of the history of the arrival of Islam in the Indonesian archipelago which emphasized more on the role of Indian Islamic scholars in the process of Islamization. As [19] noted in his study, cultural schemata can easily be activated through nativizing texts. In simple terms, the work of cultural nativization is to marginalize the role of Islam and the Arab nation in shaping the Indonesian cultural identity.

\section{CONCLUSION}

By referring to the visual semiotic analysis of the Sultan Agung 2018 movie poster as an artifact of urban design, there exists cultural nativization contents that portrays the character of Islam in Javanese land in a historical perspective formed by colonial authorities. Colonialism which formally ended since Indonesian independence in 1945 still leaves an ambivalent mentality, a characteristic generally found in the former colonized nation. On one hand, there is an attempt to reconstruct historical narratives by ex-colonized nations that are now independent. However, on the other hand, the narrative is still laden with historical constructs written by the colonialists and orientalists. Historical writings compiled by orientalist scientists later became a reference in the process of searching for cultural identities nowadays. The result is a process of de-Islamization apparent in the creation of visual design products that fill the spaces within the urban society which contain historical content of the Indonesian archipelago.

The work of cultural nativization seen in the Sultan Agung 2018 movie poster design then actively participated in the process of collective memory forming in the urban communities related to the history of Sultan Agung itself. Amidst the political rivalries between secular nationalist and religious groups today, the design of the Sultan Agung 2018 movie poster became an ammunition that supported the secular nationalist groups. Islam as a cultural product that is laden with Arabic culture influence is marginalized to construct a more syncretic Islam laden with pre-Islamic Javanese culture influence. Thus, the glorification of the history of Indonesian archipelago is made closer to the glory of the Indonesia in pre-Islamic era such as the glory of Majapahit and Sriwijaya Kingdom.

\section{REFERENCES}

[1] A. Christianna and M. Pranata, "Karakteristik Desain Poster Film Animasi Amerika Serikat," Nirmana, vol. 12, no. 1, pp. 26-35, Jan. 2012.

[2] M. Graves and E. Rechniewski, "From Collective Memory to Transcultural Remembrance," PORTAL J. Multidiscip. Int. Stud., vol. 7, no. 1, p. 7, Jan. 1970.

[3] A. W. Pratiknya, Pesan Perjuangan Seorang Bapak: Percakapan antar Generasi. Jakarta: Dewan Dakwah Islamiyah Indonesia, 1989.

[4] S. M. N. Al-Attas, Islam dalam Sejarah dan Kebudayaan Melayu. Bandung: Mizan, 
1990.

[5] N. Nilamsari, "Memahami Studi Dokumen dalam Penelitian Kualitatif," Wacana J. Ilm. Ilmu Komun., vol. 13, no. 2, pp. 177-181, 2014.

[6] E. B. Feldman, Art as Image and Idea. New Jersey: Prentice Hall, Inc, 1967.

[7] Y. A. Piliang, Semiotika dan Hipersemiotika: Gaya, Kode dan Matinya makna. Bandung: Matahari, 2012.

[8] W. Sukarwo, M. Fauzie, and A. F. Muntazori, "Karakter Visual Oom Pasikom dan Wacana Nasionalisme Sekular di Indonesia," in Seminar Nasional Desain dan Media, 2017, pp. 237-246.

[9] E. W. Said, Orientalism: Western Conceptions of the Orient, with a new Afterword. London: Penguin Books, 1995.

[10] H. Bhabha, The Location of Culture. London: Routledge, 1994.

[11] T. A. Bachtiar, Sejarah Nasional Indonesia Perspektif Baru. Bogor: Andalusia Islamic Education \& Management Services (AIEMS), 2011.

[12] C. Brants and K. Klep, "Transitional justice: History-telling, collective memory, and the victim-witness," Int. J. Conf. Violence, vol. 7, no. 1, pp. 36-49, 2013.

[13] J. K. Olick, "Collective memory: The two cultures," Sociol. theory, vol. 17, no. 3, pp. 333-348, 1999.

[14] D. J. Leichter, "Collective Identity and Collective Memory in the Philosophy of Paul Ricoeur," Études Ricoeuriennes / Ricoeur Stud., vol. 3, no. 1, pp. 114-131, 2012.

[15] A. Kusno, Ruang Publik, Identitas, dan Memori Kolektif: Jakarta Pasca-Suharto. Yogyakarta: Ombak, 2009.

[16] H. F. Reading, Kamus Ilmu-Ilmu Sosial. Jakarta: Rajawali, 1986.

[17] S. B. O. Ekundayo, "Suggested Spelling Reform in Educated Nigerian English (ENE)," SAGE Open, vol. 4, no. 2, p. 215824401453674 , Jun. 2014

[18] H. Algadri, Islam dan Keturunan Arab: dalam pemberontakan melawan Belanda. Bandung: Mizan, 1996.

[19] Y. Demir, "The Effect of Background Knowledge and Cultural Nativization on Reading Cimnprehension and Vocabulary Inference,” J. Educ. Instr. Stud. World, vol. 2, no. 4, pp. 188-198, 2012. 